\title{
Philip Ernest Converse (1928-2014): A Pioneer in Survey Research and Quality of Life Studies
}

\author{
Richard J. Estes
}

Received: 18 January 2015 / Accepted: 19 January 2015 /Published online: 27 January 2015 (C) Springer Science+Business Media Dordrecht and The International Society for Quality-of-Life Studies (ISQOLS) 2015

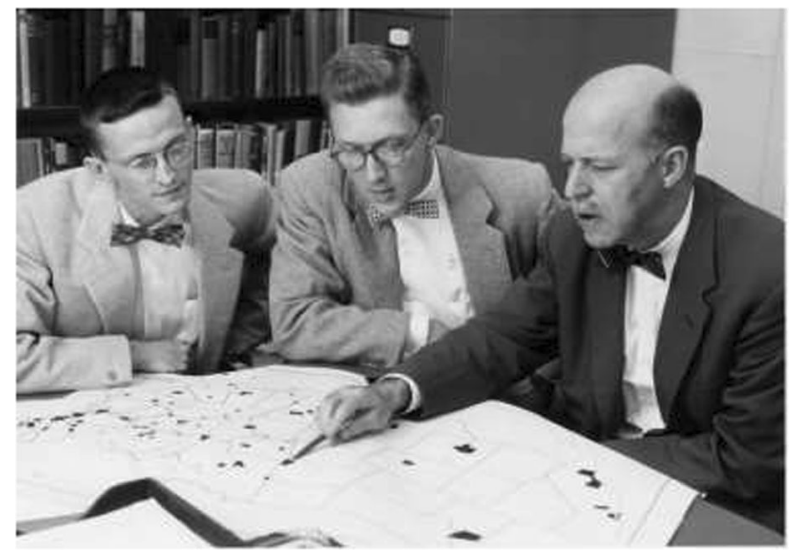

Phillip Converse, Warren Miller, and Angus Campbell (left to right) discussing the National Election Study in 1956.

(Photo credit: University of Michigan Institute of Social Research).

Philip Converse was one of the most esteemed early scholars in the field of survey research and quality of life studies. He was a seminal figure in the field of public opinion research. His article "The Nature of Belief Systems in Mass Publics" held that public opinion tended to be not very consistent across issues, not very stable over time, and not very understanding of ideology (Apter 1964). He provided additional empirical evidence in support of this assertion in a volume on The American Voter edited with Angus Campbell, Warren Miller and Donald Stokes - another foundational volume in the early years of survey research and quality of life studies (Campbell et al. 1960; 1966). The latter study was carried out using data from the time-series National

R. J. Estes $(\bowtie)$

School of Social Policy \& Practice, University of Pennsylvania,

311 Woodside Avenue, Narberth, PA, USA

e-mail: restes@sp2.upenn.edu 
Election Studies, a set of important surveys of American public opinion carried out jointly by the University of Michigan Survey Research Center and the University's Center for Political Studies with which Converse associated himself throughout his lifelong career at the University of Michigan.

At Michigan, Converse served as head of the Center for Political Studies and later as Director of the Institute of Social Research (ISR). He retired from the University in 1989 as the Robert Cooley Angell Distinguished University Professor of Sociology and Political Science and subsequently became Director of the Center for Advanced Studies in the Behavioral Sciences at Stanford University. In a tribute to Prof. Converse, Dr. Donald Kinder, Philip E. Converse Distinguished University Professor at the University of Michigan, wrote,

Over the course of his career, Converse was responsible for an extraordinary number of foundational works in the behavioral study of politics. He wrote on social class, belief systems, voters and elections, the dynamics of partisanship, political representation, the development and stabilization of party systems, and the human meaning of social change. Brilliant analyst and splendid writer, Converse delivered pleasure on nearly every page.

Phil is gone, and those fortunate to call him friend and colleague and knew him as a humane and generous spirit, will miss him keenly (Ritter 2015).

Converse earned his Ph.D. degree in Political Science from the University of Michigan. He was elected a Fellow of the American Academy of Arts and Sciences in 1969, one of that country's preeminent Associations of leading scholars. Dr. Converse died of lung disease on December 30, 2014 at age 86.

\section{Selected References}

Apter, D. E. (Ed.). (1964). Ideology and discontent. New York: Free Press of Glencoe.

Campbell, A., Converse, P. E., Miller, W. E., \& Stokes, D. E. (Eds.). (1960). The American Voter. New York: John Wiley.

Campbell, A., Converse, P., Miller, W. E., \& Stokes, D. F. (Eds.). (1996). Elections and the political order. New York: John Wiley.

Ritter, D. (2015). Philip Converse: A Tribute. Retrieved January, 2015 from http://www.washingtonpost.com/ blogs/monkey-cage/wp/2015/01/06/the-political-scientist-philip-converse-has-died/. 